
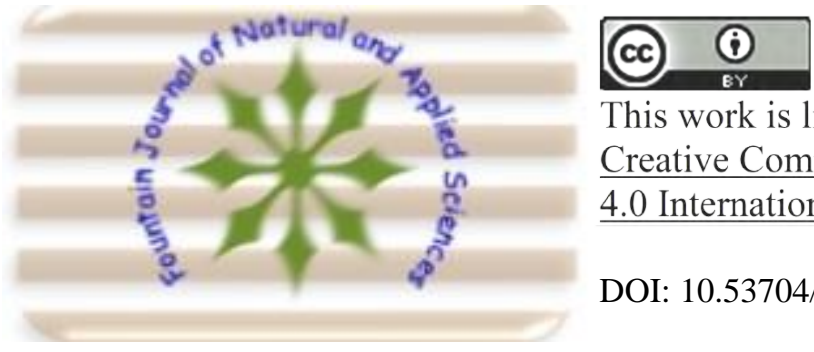

This work is licensed under Creative Commons Attribution 4.0 International License.

DOI: 10.53704/fujnas.v6i2.152

A publication of College of Natural and Applied Sciences, Fountain University, Osogbo, Nigeria. Journal homepage: www. fountainjournals.com

ISSN: 2354-337X(Online),2350-1863(Print)

\title{
Production of Proteolytic Enzyme from Catfish Waste Using Bacillus subtilis, Proteus vulgaris, and Arthrobacter aurescens
}

*Fajingbesi, A.O. and Salami, F.M.

Department of Biological Sciences, Fountain University, Osogbo, Nigeria.

\begin{abstract}
The world marine captured fishes contribute to more than $50 \%$ of the total world fish production. About $70 \%$ of fish is processed before final sale, resulting in $20-80 \%$ of fish waste depending on the level of processing and type of fish. The majority of fish wastes are disposed of in the ocean as well as on land. The discards from the processing plants amount to 20 million tonnes, which is equivalent to $25 \%$ of the world's total production from marine captured fisheries. The fish processing industry generates considerable amounts of by-products such as waste that includes shells, scales, fins and bone frames. Interestingly, they are all often high in protein, which can be processed into useful products. Three organisms Bacillus subtilis, Proteus vulgaris, and Arthrobacter aurescens were isolated and used in the production of the proteolytic enzyme in three different protease production media. B. subtilis, $P$. vulgaris and $A$. aurescens were observed to have produced protease best at $48 \mathrm{hr}$ of the second production, $72 \mathrm{hr}$ of the third production, and $72 \mathrm{hr}$ of first production, respectively. Fish waste should not be discarded into the environment, which can cause adverse effect on human health and environmental pollution, but rather they can be used in industries such as food industry in the production of baby foods to help break down the available protein into amino acids required by the body.
\end{abstract}

Keywords: Environmental pollution, Marine habitat, Fish processing, Food protein, Food industry

\section{Introduction}

Environmental conditions underlie fisheries productivity (Finney et al., 2002; Wynne and Cote 2007); however, fishing can have a detrimental effect on the environment via the use of habitatmoderating techniques, or the removal of functionally important species (Wynne and Cote 2007). The fish processing industry generates considerable amounts of by-products as waste that includes viscera, shells, scales, fins and bone frames.
They are all often high in protein, which can be processed into useful products. Most studies and research have been focusing on exploring environmentally friendly, efficient and costeffective methods for improving the quality of aquaculture waste before it is released to the environment (Jones et al., 2001). The three most

*Corresponding author: 07038545105

Email address: glamorousammie@gmail.com 
common methods for the utilization of aquatic waste are the manufacture of fish meat/oil, the production of silage or the use of waste in the manufacture of organic fertilizer. Fish silage exploits the endogenous enzymes. Thus, the native proteolytic bacteria associated with fish waste itself would be a better option to hydrolyze compared to other sources.

The fish industry developed around fishing ports at a time when landings were plentiful and there was little concern about environmental impacts. Nowadays, natural resources and the environment are under threat and are increasingly protected by law. Government policy is now focusing on the protection of resources, promoting sustainable utilization and reducing emissions to the environment. Fishing opportunities are reduced and waste generation and disposal are increasingly penalized. A further problem faced by the fish industry is the increasing concern about farm animal diseases, particularly those transmissible to man such as Bovine Spongiform Encephalopathy (BSE). This is resulting in the closure of some of the existing routes of waste utilization and adding further restriction and costs to waste disposal (Mahedrakar, 2000).

Catching and processing of fish generates a significant amount of waste. India alone generates $>2$ metric million tons of waste during fish processing of which 300,000 tons is generated from visceral waste (Mahedrakar, 2000). Due to its high organic content, fish waste is classified as certified waste, which is even more costly to dispose. This practice is coming under increased scrutiny to environmental issues and is becoming an increasing concern and cost burden to the whole sea-food industry(Jesperson et al., 2002)

Research has been carried out to develop methods to convert these wastes into useful products (Kristinsson and Rasco, 2000; Larsen et al., 2000; Guerard et al., 2001; Coello et al., 2002; Laufenberg et al., 2003). Possibly, more than $50 \%$ of the residue from the total fish capture is not used as food and generates about 32 million tonnes of waste (Kristinsson and Rasco, 2000). The wastes are used in production of oil, feed, enzyme etc. Among the various enzymes produced, bacterial proteases are more significant when compared with animal and fungal proteases. Moreover, among bacteria, Bacillus species are specific producers of extracellular proteases. They find their application in many fields and are important tools in studying the structure of proteins and polypeptides. The aim of this research is to produce proteolytic enzyme from catfish wastes using Bacillus subtilis, Proteus vulgaris, and Arthrobacter aurescens.

\section{Materials and Methods}

\section{Fish waste sample collection and preparation}

Fish waste sample was collected in fresh conditions from a fish processing centre at Freedom Park in Oshogbo, Osun state. The waste material was sorted out and kept in big sterile plastic bag for transportation to the laboratory for microbial analysis. The fish wastes consisted of the gills, head, and offal (guts, kidney and liver). The soil on which the fish wastes were degraded was collected and used for isolation of protease producing organisms.

\section{Isolation and identification of bacteria from the soil}

The soil sample collected was serially diluted by mixing $1 \mathrm{~g}$ in $9 \mathrm{ml}$ distilled water, to give $10^{-1}$ dilution. Consequently, serial dilutions up to $10^{-6}$ were prepared. Total Bacterial Count (TBC) and Total Proteolytic Bacterial Count (TPBC) of each sample were determined using standard methods on Nutrient Agar and Skimmed Milk Agar respectively. A portion $(0.1 \mathrm{ml})$ of the $10^{-4}, 10^{-5}$ and $10^{-6}$ dilutions was employed for plating. Isolates which showed clear zones on Skimmed Milk Agar were subjected to Gram staining. The isolates were gram stained and further characterized based on their reactivity to various biochemical tests like catalase test, starch hydrolysis, urease, citrate utilization test, etc. (Waites et al., 2008).

\section{Selection of proteolytic isolate}

Clear zones produced by the isolates on Skimmed Milk agar plates were measured. Thus, the proteolytic isolates which exhibited the highest proteolytic activity (determined by the extent of clear zone around the colony) were selected for further analysis (Bhunia et al., 2010). 
Effect of $\mathrm{pH}$ on selected proteolytic isolate

Skimmed Milk Agar plates with different $\mathrm{pH}$ values (7, 9 and 13) were prepared and inoculated with the cultured isolate for determining the effect of $\mathrm{pH}$ on the proteolytic activity of the isolates (Bhunia et al., 2010).

Effect of temperature on selected proteolytic isolates at $\mathrm{pH} 9$

Skimmed Milk Agar plates with pH 9 were prepared and inoculated with the selected isolates and incubated at different temperatures $\left(25^{\circ} \mathrm{C}, 35^{\circ} \mathrm{C}\right.$, $45^{\circ} \mathrm{C}$ ) for determining the effect of temperature on its proteolytic activity (Bhunia et al., 2010).

\section{Protease production}

The selected proteolytic isolates were cultured in protease production media containing $2 \% \quad \mathrm{NH}_{2} \mathrm{SO}_{4}$ $(w / v), 1 \% \quad K_{2} H_{P O}(w / v), 1 \% K_{2} H_{2} P_{4}(w / v), 0.4 \%$ $\mathrm{MgSO}_{4} .7 \mathrm{H}_{2} \mathrm{O}(\mathrm{w} / \mathrm{v}), 0.01 \% \mathrm{MnSO}_{4}(\mathrm{w} / \mathrm{v}), 0.01 \%$ $\mathrm{Fe}_{2} \mathrm{SO}_{4.7} \mathrm{H} 2 \mathrm{O}(\mathrm{w} / \mathrm{v}), 1 \%$ yeast extract $(\mathrm{w} / \mathrm{v}), 10 \%$ peptone $(w / v)$ with $\mathrm{pH} 9$ maintained at $35^{\circ} \mathrm{C}$ for 24 to 72 hours in a shaker incubator ( $140 \mathrm{rpm})$. The second protease production media subjected for protease production was the sterilized remaining part of homogenized fish juice. The third production media used for protease production was $90 \mathrm{ml}$ production media mixed with $10 \mathrm{ml}$ sterilized homogenized fish juice (Nurullah, 2012).

\section{Extraction of enzyme}

Cells were harvested by centrifugation at 10000 rpm for 10 minutes at $4^{\circ} \mathrm{C}$. The precipitate containing the cell debris was discarded and the supernatant was treated with $70 \%$ ammonium sulphate solution and allowed to stand at $4{ }^{\circ} \mathrm{C}$ overnight. The precipitate was centrifuged at $10000 \mathrm{rpm}$ for 20 minutes at $4{ }^{\circ} \mathrm{C}$ and the residue was dissolved in $0.9 \%$ $\mathrm{NaCl}$ and labelled as crude protease extract. The process of extraction of crude protease was repeated for all the media used above. The crude enzyme was partially purified using ammonium sulphate solution (60\% saturation). The precipitated enzyme was used as a crude protease (Yang et al., 2000).

\section{Proteolytic activity profile}

The proteolytic activity of crude protease extract was assayed at $\mathrm{pH}$ 4-10 using the following buffersCitrate phosphate buffer ( $\mathrm{pH} 4$ and 5), Phosphate buffer solution ( $\mathrm{pH} 6-8)$, Glycine- $\mathrm{NaOH}$ buffer $(\mathrm{pH}$ 9 and 10). The assay mixture consisted of $1.25 \mathrm{ml}$ of respective buffers, $0.5 \mathrm{ml}$ of casein as substrate and $0.25 \mathrm{ml}$ of enzyme extract. The reaction was stopped by adding $3 \mathrm{ml}$ of $5 \%$ Tricyclic antidepressant (TCA) after holding it at $37^{\circ} \mathrm{C}$ for 30 minutes. The final mixture was filtered and TCA soluble peptides in filtrate were quantified by measuring the absorbance at $540 \mathrm{~nm}$ using Biuret's working solution (Yang et al., 2000).

\section{Results}

Soil samples were serially diluted and dilutions of $10^{-4}, 10^{-5}$, and $10^{-6}$ were plated on Nutrient Agar, and Skimmed Milk Agar. The total bacterial count and total proteolytic bacterial count carried out on the isolates showed that the organisms present in the soil are the ones that will be capable of producing protease enzyme. Table 1 shows the morphology of the proteolytic bacteria present in the soil sample.

Table 1: Morphological characteristics of isolates on Skimmed Milk Agar

Observation

$\begin{array}{llll}\text { Morphology } & A & B & C\end{array}$

$\begin{array}{llll}\text { Colour } & \text { Creamy } & \text { Creamy } & \text { Creamy } \\ \text { Elevation } & \text { Raised } & \text { Flat } & \text { Flat } \\ \text { Surface } & \text { Moist } & \text { Dry } & \text { Moist } \\ \text { Edges } & \text { Irregular } & \text { Regular } & \text { Regular }\end{array}$

Key: A-Isolates on Dilution of $10^{-4}, B$ - Isolates on Dilution of $10^{-5}$ and $C$ - Isolates on Dilution of $10^{-6}$

Table 2 shows the biochemical tests carried out on isolates that shows clear zone on Skimmed Milk Agar. Isolates were suspected to be; $A$ is $B$. subtilis, isolate $B$ is $P$. vulgaris, isolate $C$ is $A$. aurescens. 
Table 2: Tests on isolates that shows clear zone on Skimmed Milk Agar.

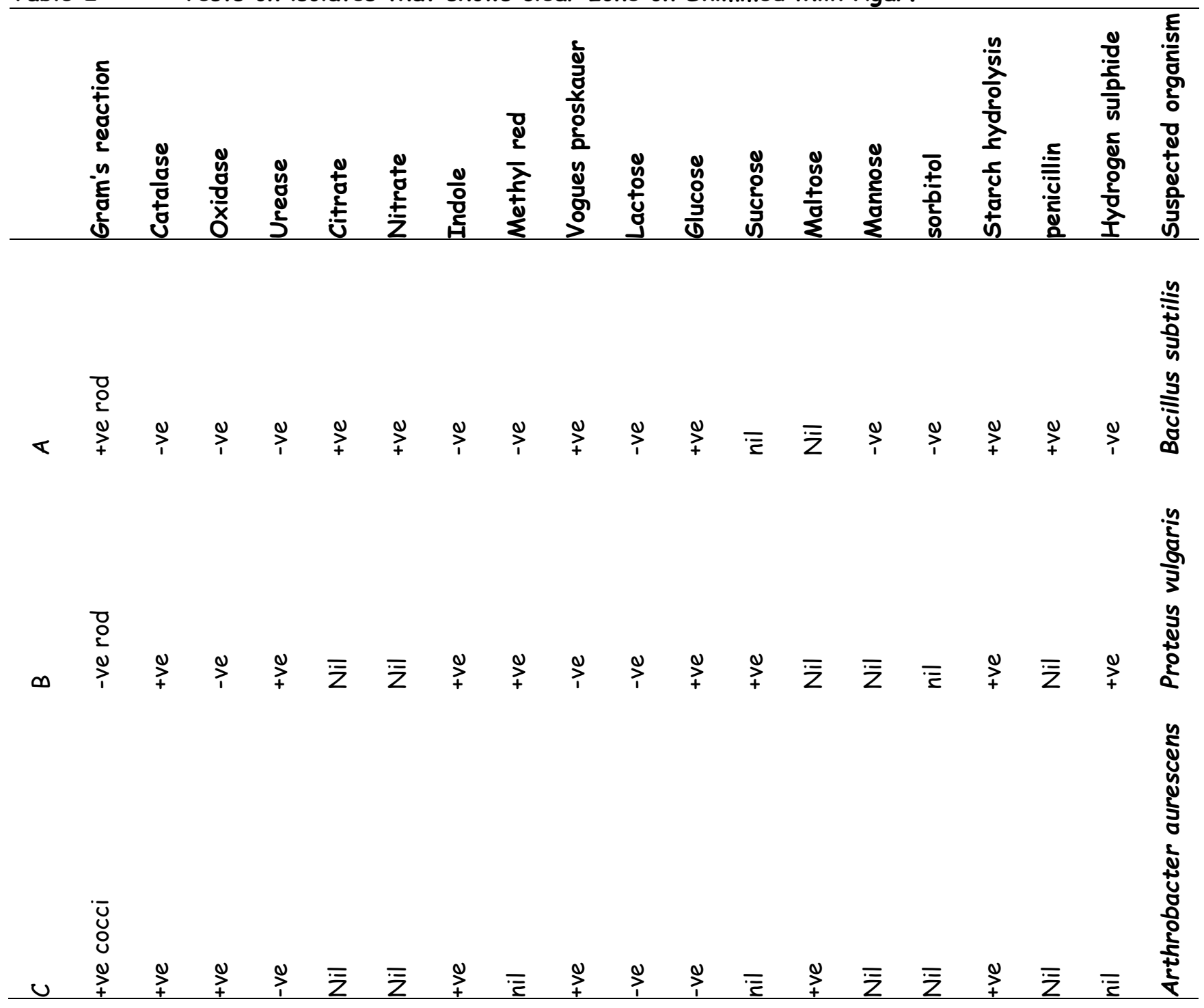

Table 3 shows the proteolytic activities of the three isolates when grown on Skimmed Milk Agar. B. subtilis shows effective clear zone, which increases consecutively for 72 hours. P. vulgaris also shows an effective clear zone which increases consecutively for 72 hours. A. aurescens shows a perfect and effective clear zone which increases at 48 hours and a full clear zone at 72 hours.

Table 3: $\quad$ Proteolytic activities of the isolates

\begin{tabular}{lccc}
\hline Isolate & $\begin{array}{c}\text { Clear zone at 24 hours } \\
\text { Radius }(\mathrm{cm})\end{array}$ & $\begin{array}{c}\text { Clear zone at } 48 \text { hours } \\
\text { Radius }(\mathrm{cm})\end{array}$ & $\begin{array}{c}\text { Clear zone at } 72 \text { hours } \\
\text { Radius }(\mathrm{cm})\end{array}$ \\
\hline $\begin{array}{l}\text { Bacillus subtilis } \\
\text { Proteus vulgaris }\end{array}$ & 0.2 & 0.4 & 1.1 \\
$\begin{array}{l}\text { Arthrobacter } \\
\text { aurescens }\end{array}$ & 0.1 & 0.4 & 1.0 \\
aul cleared & \\
\hline
\end{tabular}


Table 4 shows the effect of $\mathrm{pH}$ variation on the proteolytic activity of the three isolates on Skimmed Milk Agar plate. The best proteolytic activity was recorded at $\mathrm{pH} 9$ with $B$. subtilis showing a zone of inhibition of about $3.0 \mathrm{~mm}$ which was then followed by $P$. vulgaris with a zone of inhibition of about 2.7 $\mathrm{mm}$ and $A$. aurescens with a zone of inhibition of about $1.8 \mathrm{~mm}$. The least proteolytic activity was recorded at $\mathrm{pH} 7$.

Table 4:

Effect of $\mathrm{pH}$ on the isolates

\begin{tabular}{llll}
\hline Isolate & $\mathrm{pH} 7$ & $\mathrm{pH} 9$ & $\mathrm{pH} 13$ \\
\hline Bacillus subtilis & 0.6 & 3.0 & 2.2 \\
$\begin{array}{l}\text { Proteus vulgaris } \\
\text { Arthrobacter }\end{array}$ & 0.5 & 2.7 & 1.5 \\
\begin{tabular}{l} 
aurescens \\
\hline
\end{tabular} & 0.3 & 1.8 & 1.0 \\
\hline
\end{tabular}

Table 5 shows the effect of temperature at $\mathrm{pH} 9$ on the three isolates on Skimmed Milk Agar. B. subtilis showed a high proteolytic activity potential at a temperature of $45^{\circ} \mathrm{C}$ followed by that of $25^{\circ} \mathrm{C}$ and the least activity was observed when grown at $35^{\circ} \mathrm{C}$. The same activity was observed with $P$. vulgaris and $A$. aurescens.

Table 5: Effect of temperature on the isolates on Skimmed Milk Agar at $\mathrm{pH} 9$

\begin{tabular}{|c|c|c|c|}
\hline Isolates & $25^{\circ} \mathrm{C}$ & $35^{\circ} \mathrm{C}$ & $45^{\circ} \mathrm{C}$ \\
\hline $\begin{array}{l}\text { Bacillus } \\
\text { subtilis }\end{array}$ & 2.6 & 1.0 & 2.8 \\
\hline $\begin{array}{l}\text { Proteus } \\
\text { vulgaris }\end{array}$ & 0.9 & 0.6 & 2.8 \\
\hline $\begin{array}{l}\text { Arthrobacter } \\
\text { aurescens }\end{array}$ & 1.7 & 1.0 & 3.4 \\
\hline
\end{tabular}

Figure 1 shows the protease of $B$. subtilis at $37^{\circ} \mathrm{C}$, $\mathrm{pH} 9$ at various time intervals. At 48 hours, second protease production media tends to produce the highest concentration of enzyme when quantified using Biuret working solution.

At 24 hours, enzyme production seems to be slightly different from 0 hour while 72 hour has the lowest enzyme production. The concentration of enzyme produced by the organism tends to increase at 0,24 and 48 hours respectively with a slight decline observed at 72 hours for the first protease production media. For the third protease production media, the organism produced the highest concentration of protease enzyme at 24 hours with a slight reduction at 48 hours followed by 72 hours and 0 hour with the lowest production.

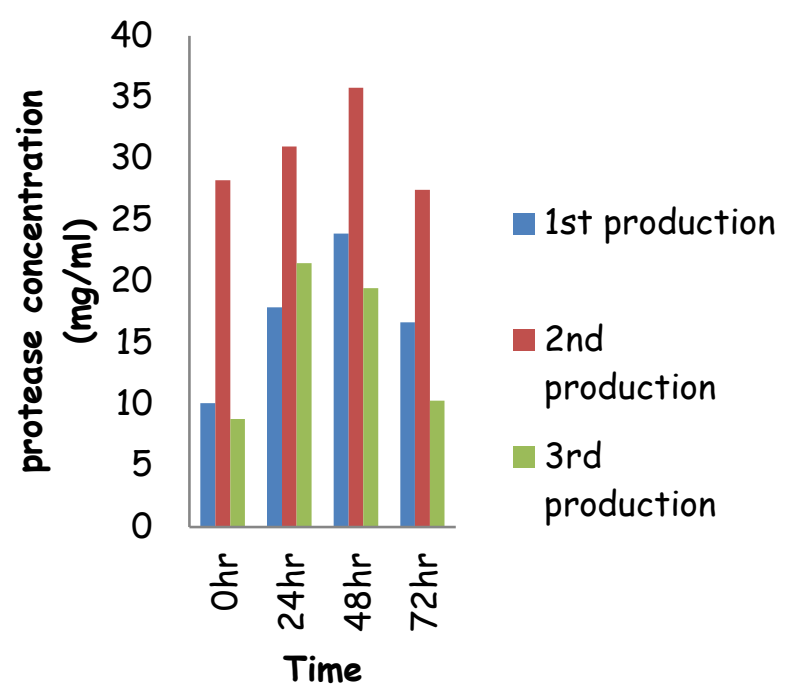

Figure 1: Protease production at $37^{\circ} \mathrm{C}, \mathrm{pH} 9$ using $B$. subtilis at $0,24,48$ and $72 \mathrm{hr}$.

Keys: First production - contains $400 \mathrm{ml}$ of broth media + microorganism.

Second production - contains $400 \mathrm{ml}$ of broth media + microorganism $+10 \mathrm{ml}$ of sterilized fish juice and third production - contains $90 \mathrm{ml}$ of broth media + microorganism $+10 \mathrm{ml}$ of fish juice.

Figure 2 shows the production of protease at $37^{\circ} \mathrm{C}$, pH 9 using P. vulgaris. At 0, 24, 48 and 72 hours, each production increases steadily. The organism produced the protease enzyme best at 72 hours of third protease production media when compared to the first and second protease production media.

Keys: First production - contains $400 \mathrm{ml}$ of broth media + microorganism, second production - contains $400 \mathrm{ml}$ of broth media + microorganism $+10 \mathrm{ml}$ of sterilized fish juice and third production - contains $90 \mathrm{ml}$ of broth media + microorganism $+10 \mathrm{ml}$ of fish juice.

Figure 3 shows the production of protease at $37^{\circ} \mathrm{C}$, $\mathrm{pH} 9$ using $A$. aurescens. The organism produced the protease enzyme best at 72 hours of first protease production media when compared to the second 


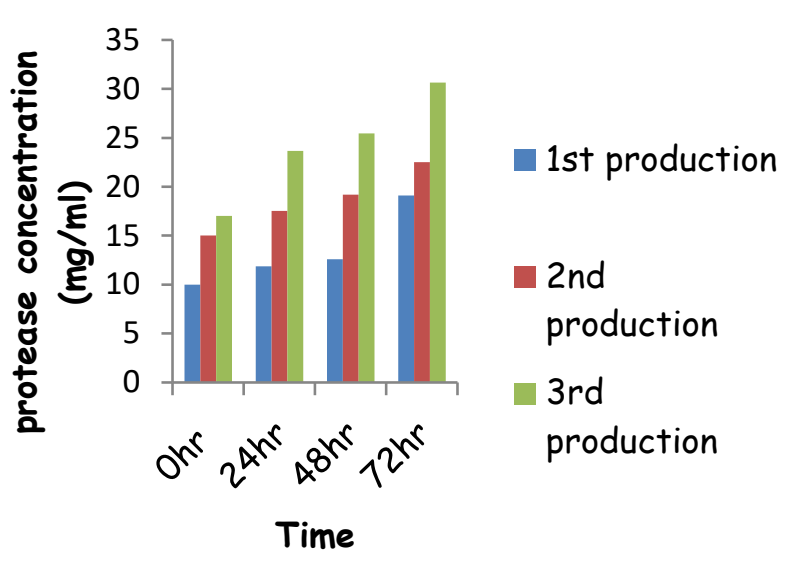

Figure 2: Protease production at $37^{\circ} \mathrm{C}, \mathrm{pH} 9$ using $P$. vulgaris at $0,24,48$, and $72 \mathrm{hr}$.

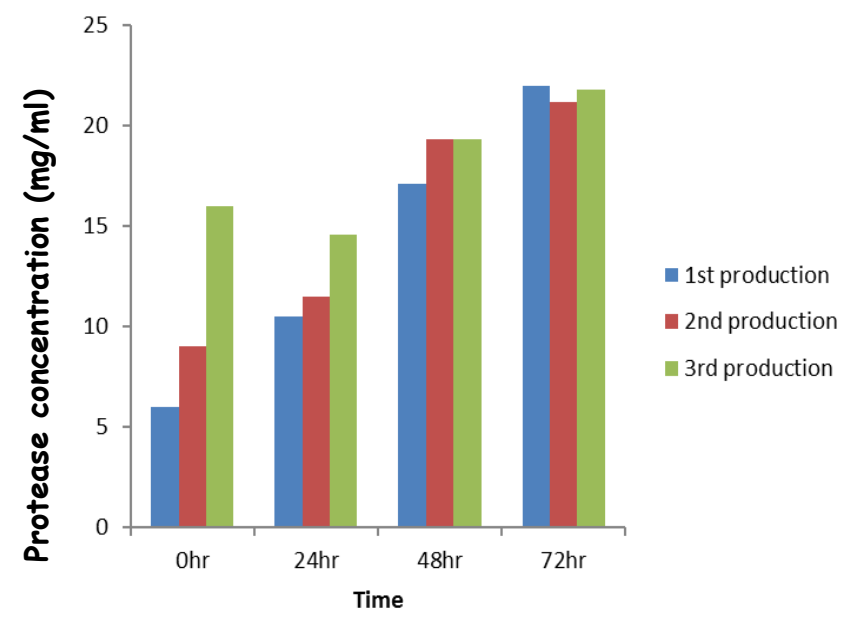

Figure 3: Protease production using $A$. aurescens at $0,24,48$ and $72 \mathrm{hr}$.

and third protease production media. At $0 \mathrm{hr}, 24 \mathrm{hr}$, $48 \mathrm{hr}$, and $72 \mathrm{hr}$, the first and second production increased steadily, with variation in the third production.

Keys: first production - contains $400 \mathrm{ml}$ of broth media + microorganism, second production - contains $400 \mathrm{ml}$ of broth media + microorganism $+10 \mathrm{ml}$ of sterilized fish juice and third production - contains $90 \mathrm{ml}$ of broth media + microorganism $+10 \mathrm{ml}$ of fish juice.

\section{Discussion}

In this study, the proteolytic bacteria isolated included $B$. subtilis, $P$. vulgaris and $A$. aurescens, which is in agreement with the results of Kumaran et al. (2013). B. subtilis was observed to be most effective at $\mathrm{pH} 9$ and temperature $45^{\circ} \mathrm{C}$ compared to $P$. vulgaris and $A$. aurescens.

When compared to the other two organisms, $B$. subtilis showed the best production of protease enzyme at $48 \mathrm{hr}$ of second enzyme production media.

At 24, 48, and $72 \mathrm{hr}$, first and second enzyme production media varied with an increment in biomass and colour of the second enzyme production media despite them having the same volume. This could be as a result of difference in the constituents of the media which is the presence of the fish juice in the second enzyme production media which is absent in the first enzyme production. Second and third enzyme production media were as well different despite similar constituents. This could be as a result in the low volume of the broth medium used for the third enzyme production media making it possible for the organism to produce proteolytic enzyme best at $24 \mathrm{hr}$ since the volume is low but it has the same volume of fish juice and microorganism which in turn increases its level of productivity.

Production of protease enzyme was observed best with $P$. aurescens at 24, 48, and $72 \mathrm{hr}$. There was a gradual increment in the protease concentrations by the organism in the three enzyme production media with respect to time as compared to $B$. subtilis. This could be as a result of difference in the volume of media and also the addition of the fish juice which was not present in the first enzyme production medium.

Production of protease by $A$. aurescens was observed at 0,24, 48, and $72 \mathrm{hr}$. Between 0 and 24 $\mathrm{hr}$, there was a gradual increment in the three enzyme production media with respect to time. At 48 $\mathrm{hr}$, the first and second enzyme production media differed with an increment in biomass of the second enzyme production medium which could be as a result of the differences in the constituents of the production media.

\section{Conclusion}

The organisms, B. subtilis, $P$. vulgaris, and $A$. aurescens can be used in the production of protease enzyme. $P$. vulgaris was the best of all due to the increment in the production of the protease enzyme 
at 72 hours of the third production which was apparent as a result of an increment in the volume of biomass produced. Fish waste will be a cheap source of medium for protease enzyme production. Environmental factors such as $\mathrm{pH}$ and temperature, constituent of the production medium and volume of the production medium were factors considered in the production of the enzyme.

\section{Recommendation}

Protease is an enzyme present in the digestive tract of animals including fish guts. Fish waste should not be discarded into the environment which can cause adverse effect to health and lead to environmental pollution. Fish waste can be used as a raw material in the production of an essential enzyme (protease) used as an immobilized enzyme in industries such as food industries in the production of baby foods which contains large proteins to help in the breakdown of the proteins into amino acids that can be easily utilized by them. Also, fish can be used to produce fish oil which can be used in the production of margarine, omega-3 fatty acids.

\section{References}

Bhunia, B., Dutta, D. and Chaudhari, S. (2010). Selection of suitable carbon, nitrogen and sulphate source for the production of alkaline protease by Bacillus licheniformis NCIM - 2042. Notulae Scientia Biologicae 2(2), 56 -59.

Coello, N., Montiel, E., Concepcion, M. and Christen, P. (2002). Optimization of a culture medium containing fish silage for L-lysine production by Corynebacterium glutamicum.mmm Bioresource Technology, 85: 207-211.

Finney, B. P., Gregory-Eaves, I. M., Douglas, S. V. and Smol, J. P. (2002). Fisheries productivity in the northeastern Pacific Ocean over the past 2,200 years. Nature 416:729-733.

Guerard, F., Dufosse, L., De La Broise, D. and Binet, A. (2001). Enzymatic hydrolysis of proteins from yellow fin tuna (Thunnus albacares) wastes using Alcalase. Journal of Molecular Catalysis B: Enzymatic, 11: 1051-1059.
Jesperson, C., K. Christiansen and Hummelmose, B. 2000. Cleaner production assessment in fish processing. United Nations Environment Programme and Danish Environmental Protection Agency. pp. 99.

Jones, A. B., Dennison, W. C. and Preston, N. P. (2001). Integrated treatment of shrimp effluent by sedimentation, oyster filteration and macroalgal absorption: a laboratory scale study. Aqualculture. (193): 155-178.

Kristinsson, H.G. and Rasco, B.A. (2000). Fish protein hydrolysates: production, biochemical, and functional properties. Critical Reviews in Food Science and Nutrition, 40: 43-81.

Kumaran, E., Mahalakshmibriya, A. and Sentila, R. (2013). Effect of fish waste based Bacillus Protease in silver recovery from waste X-Ray Films. International journal of current microbiology and applied sciences. 2(3): 49.56.

Larsen, T., Thilsted, S.H., Kongsback, K. and Hanse, M. (2000). Whole small fish as a rich calcium source. British Journal of Nutrition, 83: 191-196.

Laufenberg, G., Kunz, B. and Nystroem, M. (2003). Transformation of vegetable waste into value added products. Bioresource Technology, 87: 167198.

Mahedrakar, N.S., 2000. Aqua feeds and meat quality of cultured fish. Biotech consort India Ltd, New Delhi, pp.2630.

Nurullah, A. (2012). Production of extracellular protease in submerged fermentation by Bacillus Licheniformis ATCC 12759. African Journal of Biotechnology. 11(7): 1729- 1735.

Waites, M.J., Morgan, N.L., Rockey, J.S. and Higton, G. (2008). Industrial Microbiology an Introduction London: Blackwell Publisher.

Wynne, S. P. and Cote. I. M. (2007). Effects of habitat quality and fishing on Caribbean spotted spiny lobster populations. Journal of Applied Ecology 44:488-494.

Yang, J.K., Tzeng, I.L. and Wang, S.L. (2000). Production and Purification of protease from a Bacillus subtilis that can deproteinize crustacean wastes. Enzyme Microbiology Technology. 26: 406-413. 